\title{
CHANGING RURAL ECONOMIES: THEORETICAL BACKGROUND AND EMPIRICAL EVIDENCE
}

\author{
Vladan HRUŠKA ${ }^{1} \bullet$ Konrad CZAPIEWSKI ${ }^{2}$ \\ ${ }^{1} J a n$ Evangelista Purkyně University in Ústí nad Labem, Faculty of Science \\ Department of Geography, České mládeže 8, 400 96, Ústí nad Labem, Czechia \\ vladan.hruska@ujep.cz \\ ${ }^{2}$ Institute of Geography and Spatial Organization, Polish Academy of Sciences \\ Twarda 51/55, 00-818 Warsaw, Poland \\ konrad@twarda.pan.pl
}

\begin{abstract}
Rural areas have been traditionally perceived as space dominated by agriculture. However, especially since the World War II a sinking importance of agriculture for the economy, employment and even identity building could be observed. This has occurred both in developed capitalist and post-socialist countries. The purpose of this article is to discuss the character of present rural economies of developed countries (and especially Visegrad countries) with a particular attention to other than acricultural and tourism economic industries. Key factors influencing the growth of jobs in non-farming and tourism sectors are analysed and on this basis the conditions for entrepreneurship in rural areas in the era of the knowledge economy are re-evaluated.
\end{abstract}

Key-words: rural economy, economic restructuring, entrepreneurship, manufacturing, Visegrad countries, developed countries.

\section{Introduction}

Rural areas have been traditionally perceived as stable, unchanging or even backward places which successfully (or unsuccessfully) keep away from modernization pressures. By contrast, cities have been perceived as symbols of progress, as dynamic places which undergo rapid development with all its negative or positive consequences. However, this dichotomy of traditional rural and dynamic urban appears to be baseless. At least in the context of Western developed countries where rural space is influenced by permanent social, economic and political changes which have accelerated significantly in the post-World War II period (Woods 2005). These changes related to broader processes of social and economic transformation from regional, national or even global scales significantly and have transformed traditional rural economies originally dependent on primary economic activities - planting crops and wood, livestock breeding, production of timber and the mining of raw material. 
As a result, rural areas have been significantly influenced by the sinking importance of agriculture for the economy, employment and even identity building after the productivist period in which farming had a key role in national and rural economies (e.g. Ilbery and Bowler 1998; Woods 2005; Lapping 2006). This has happened both in developed capitalist and post-socialist countries. Whereas in the context of the United Kingdom and some other Western countries the 1980s are labelled as a period of "crisis in farming" (Woods 2005), "crisis of productivism" (Lowe et al. 1993) or "end of the productivist phase" (Ilbery and Bowler 1998), in post-socialist countries such substantial and rapid changes in the farming sector came at the beginning of the 1990s. Since then, the importance of the primary economic sector for rural areas is sinking in terms of its benefits for employment and income of rural inhabitants (Atterton et al. 2012).

On the other hand it does not mean that rural areas, since the proclaimed end of productivism, are some kind of "job deserts" as it is very often heard in lay discourse commentaries of the post-socialist transformation of agriculture in Visegrad countries. Instead, new job opportunities have been generated in other sectors of the economy - in services or even manufacturing - as a result of the development of ICT, growing individual automobility, by the influx of well qualified and wealthy members of middle and higher classes to rural areas, etc. In circumstances like these, manufacturing and services became more important for rural employment than farming. However, the spatial distribution of these "new" jobs in rural areas is very uneven and this is also one of the factors which causes growing socio-economic differentiation of rural areas since the gradual retreat of agriculture.

The purpose of this article is to discuss the character of non-agricultural rural economies of developed countries and in particularly of Visegrad countries. Finally, key factors influencing the growth of jobs in non-farming sectors are analysed and on this basis the conditions for entrepreneurship in rural areas in the era of the knowledge economy are re-evaluated.

\section{Transformation of rural economies of developed countries}

In the post-WWII period the primary goal of national states was to ensure their food security (Burton 2004, Lapping 2006). Hence, farming received very much attention from national governments in order to maximize agricultural output. Such a goal should have been reached by three structural dimensions of productivism - intensification, concentration and specialisation of agricultural production (Ilbery and Bowler 1998) - and required an extensive array of legislation, financial and institutional tools which should have helped farmers to increase their agricultural output (Lapping 2006). This productivist thinking has significantly influenced rural policies which are till now very often perceived as equal to sectoral agricultural policies, at least in the UK and the US (Atterton et al. 2012: 125).

However, the contribution of productivist agriculture to the general development of rural areas is highly disputable. Among other things, labour specialization and mechanization of farm processes reduced the agricultural workforce in developed market economies (Woods 2011: 76). As a result, in the 1970s, the rural areas of many developed countries lost their exclusive economic dependence on agriculture, as the percentage of the agriculture-dependent population on the total rural population in these countries decreased to less than 50 per cent (The Food and Agriculture Organization, quoted in 
Woods (2005)) and shrinkage of this population still continues. In OECD countries generally agriculture accounted for only 5.6 per cent of employment (for detailed information about each OECD country see Fig. 1).

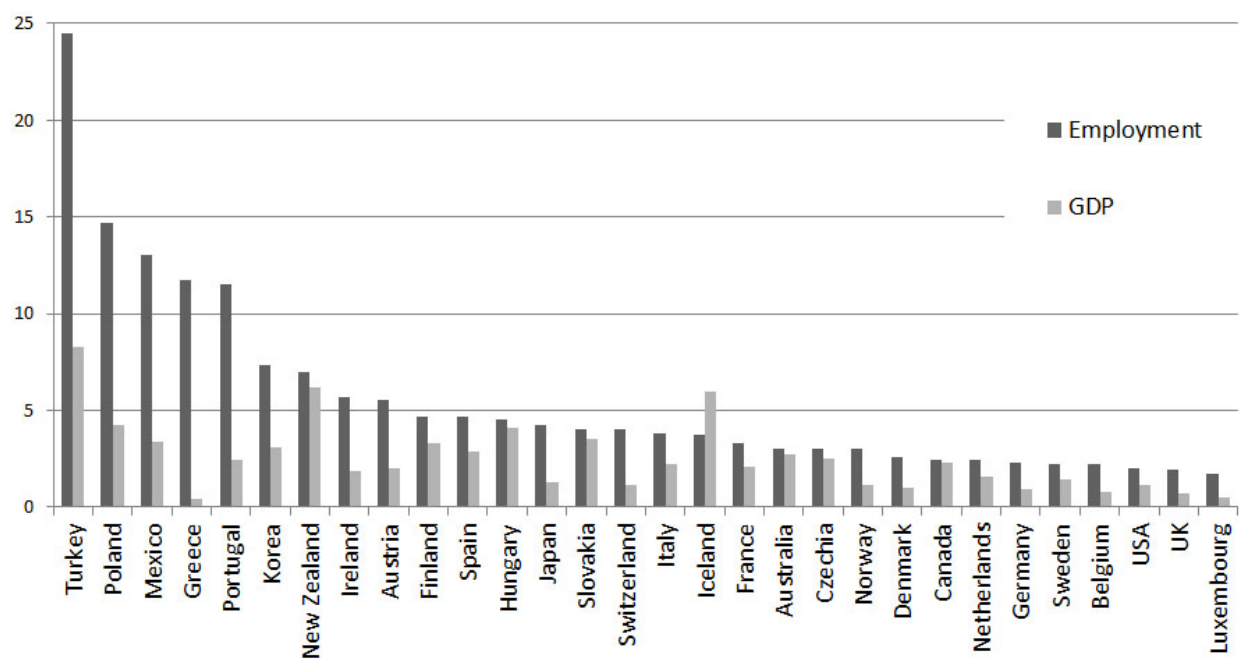

Fig. 1. Share of employment and GDP in agriculture, forestry, hunting and fishing in OECD countries ${ }^{1}$ Source: OECD (2008).

Simultaneously with the fall in employment in primary economic activities, employment in other economic sectors has been growing. Since the 1970s a new flow of capital goods and opportunities to rural areas was evidenced in Europe and North America (Marini and Mooney 2006: 95). Apart from growing tourism and other services the number of new job opportunities in manufacturing in rural areas increased, despite the general retreat of manufacturing from developed countries at the expense of services (North 1998: 161). Such development brought many Western authors to speak about rural industrialization (North 1998), industrial restructuring of rural areas (Fløysand, Sjøholt 2007) or even urban-rural shift in manufacturing (e.g. Keeble 1980; Fothergill and Gudgin 1982; Keeble et al. 1983; North 1998).

Keeble (1980) was the first to reveal the fast growth of jobs in manufacturing relative to urban areas, as he recorded it in rural areas of Western Europe and the US from the 1960s. Moreover, this growth superimposed upon the more general trend of deindustrialization of national economies (North 1998: 163). In the 1960s US manufacturing increased as a whole by 20 per cent but non-metropolitan areas reported a 31 per cent increase in comparison to a 15 per cent increase in metropolitan areas. During the $1970 \mathrm{~s}$ employment in manufacturing in metropolitan areas fell by 3.5 per cent, whereas in non-

\footnotetext{
${ }^{1}$ Employment figures are from the Annual Labour Force Statistics (ALFS) dataset, except for France and the USA which are from the Annual National Accounts dataset. Data are for 2008, except for Belgium, Greece, Luxembourg, Poland and the USA for which data are for 2007. GDP figures are gross value added at current prices from the OECD National Accounts database. Data are for 2008, except for Australia, Belgium, Czech Republic, Denmark, Finland, Germany, Ireland, Japan, Korea, Switzerland, Turkey and the USA for which data are for 2007; Mexico (2006); Iceland (2005); and Canada and New Zealand (2004), OECD (2010).
} 
-metropolitan areas it increased by 12 per cent (Lonsdale and Seyler 1979, quoted in North 1998). In rural areas of the UK employment in manufacturing increased over the period 1960-1991 by 45 per cent, whereas in urban areas (including small cities) it dropped significantly (North 1998). This trend also continued over the period 1991-1998 when the number of manufacturing jobs increased by almost 10,000 (Kiehl and Panebianco 2002). Between 1998 and 2002 a growing number of jobs was reported in rural England - 275,000 new jobs were created, most of them in business services and distribution, hotels and restaurant activities (Atterton et al. 2012: 126).

Despite the continuing deindustrialization of national economies, manufacturing also dominates rural economies of other European countries. In West Germany there was a loss of manufacturing jobs in rural areas between 1991 and 1998 (by 16.7 per cent), however this loss was lower than in urban areas. It was a similar situation in Italy over the period 1991-1996, but the decrease of manufacturing jobs was lower (-3.8). In both countries it seems that the dominance of manufacturing will soon be brought to an end by the fast growing number of jobs in the service sector (Kiehl and Panebianco 2002).

\section{Post-socialist economic transformation of rural areas in Visegrad countries}

Naturally rural areas of Visegrad countries have also undergone various processes of economic restructuring. The turn of the 1980s and 1990s has become an important milestone in the development of rural areas in former socialist states of Central Europe. The transition to a market economy, democratization and the retreat from central planning has significantly affected the fate of individual rural localities which have been going through the transformation process (Hruška 2014). Therefore, when discussing changes in rural areas of Visegrad countries - the beginning of the 1990s is the most frequent beginning of analyses of such transformations.

The transition from socialism to capitalism triggered processes typical in the developed countries of western Europe, which have, however, developed with a certain delay in Visegrad countries. During such a transition in the central system, institutional and structural changes (Synek 2004) were required in order to adjust to the new economic system. From this point of view, a key role was played by the privatization process. Its aim was not only a change in ownership patterns, but rather the whole economic transformation which should have ensured competitiveness of the newly established capitalist economies. Such a transformation also included structural changes in the structure of the economy, when the shares in agriculture and heavy industry on total employment and GDP decreased significantly at the expense of the service sector.

\section{Czechia}

The post-socialist transformation of Czech agriculture caused a rapid decline of employment in agriculture. At the beginning of the 1990s 7 per cent of economically active inhabitants (about 600,000 people) worked in agriculture (Bičík and Jančák 2005). However, in 2011 it was only 2.1 per cent (125,000 people) (Czech Statistical Office 2011). More demonstrative facts about rural employment can be received by an analysis of Czech microregions (Fig. 2). In this case, delimitation of such microregions is based on the delimitation of the administrative areas of municipalities with extended competency, which 
were established for the purposes of public administration. Delimitation of most of them is very close to functional regions based on commuting-to-work patterns; therefore they cover regional labour markets very well and are suitable for further analysis. These microregions were classified into the following categories:

- urban (includes cities with a population of more than 40,000 or includes no rural municipalities defined as municipalities with less than 3,000 inhabitants),

- rural suburban (adjacent to urban microregions around cities with a population of more than 150,000),

- intermediate rural (include rural municipalities and towns with a population of 10,000-40,000),

- rural (around towns with a population of 9,999 and less).

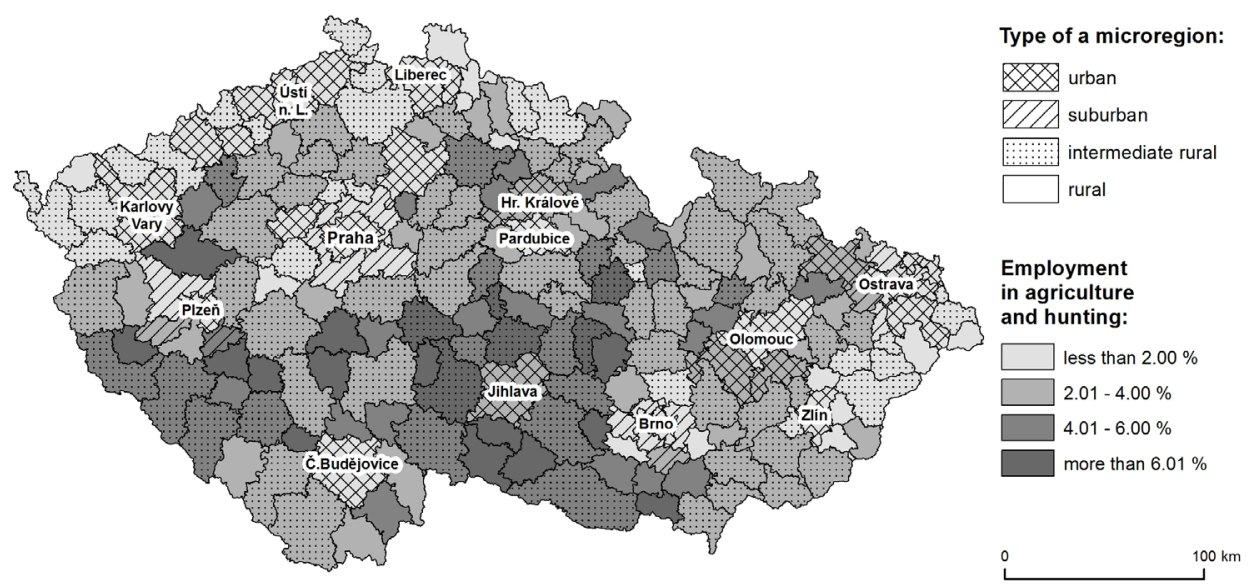

Fig. 2. Typology of Czech microregions and employment in agriculture and hunting in 2011 Source: compiled from Czech Statistical Office statistics (Census 2011), ArcČR 500; designed by V. Hruška.

Analysis of employment patterns for 2011 in these microregions shows, that in rural microregions the percentage of people employed in agriculture and hunting was 4.0 per cent (even in the microregion Pacov with the highest employment in agriculture the percentage was only 11.3) (Table 1). Moreover, it can be argued that in Czechia there is a clear urban-rural gradient in manufacturing, as employment in manufacturing was much higher in rural than in urban microregions. By contrast, the trend was the opposite if we consider employment in tourism which is very often perceived as salvation for economies of peripheral rural areas - its share on employment in rural microregions was only 3.8 per cent compared with 5.3 per cent for urban areas.

Concerning rural municipalities (defined as municipalities with more than 3,000 inhabitants) with the highest number of jobs in 2011, these are mostly municipalities whose economy is based on coal mining (Stonava - 2,518 jobs; Staříc - 1,901), the automotive industry and related industries (Nošovice - 2,091 jobs; Kvasiny - 1,809; Chotěšov - 1,701), a large industrial park with plants for transnational companies (TNCs) (Žebrák - 2,020), a nuclear power plant (Dukovany -2,006 jobs) and a heating plant (Trmice -1,980 jobs; in combination with a retail park and producer of components for the automotive industry) and agriculture (Slušovice - 1,797 jobs) (Doležal 2015). 
Table 1. Share of employment in agriculture and hunting, manufacturing and tourism in Czech microregions in 2011

\begin{tabular}{|c|c|c|c|c|c|c|}
\hline NACE section: & \multicolumn{2}{|c|}{$\begin{array}{c}\text { A } \\
\text { agriculture }\end{array}$} & \multicolumn{2}{|c|}{$\underset{\text { manufacturing }}{\mathrm{C}}$} & \multicolumn{2}{|c|}{$\begin{array}{c}\mathbf{R + l} \\
\text { Tourism }\end{array}$} \\
\hline Urban microregions & \multicolumn{2}{|c|}{0.9} & \multicolumn{2}{|c|}{17.4} & \multicolumn{2}{|c|}{5.3} \\
\hline Rural suburban microregions & \multicolumn{2}{|c|}{1.5} & \multicolumn{2}{|c|}{21.1} & \multicolumn{2}{|c|}{4.4} \\
\hline Intermediate rural microregions & \multicolumn{2}{|c|}{2.9} & \multicolumn{2}{|c|}{26.8} & \multicolumn{2}{|c|}{4.3} \\
\hline Rural microregions & \multicolumn{2}{|c|}{4.0} & \multicolumn{2}{|c|}{28.7} & \multicolumn{2}{|c|}{3.8} \\
\hline Czechia (total) & \multicolumn{2}{|c|}{2.1} & \multicolumn{2}{|c|}{22.6} & \multicolumn{2}{|c|}{4.7} \\
\hline \multirow{3}{*}{$\begin{array}{l}\text { Non-urban microregions with } \\
\text { the most extreme values }\end{array}$} & $\max$ & $\min$ & $\max$ & $\min$. & $\max$ & $\min$. \\
\hline & 11.3 & 0.3 & 43.8 & 10.8 & 16.3 & 2.2 \\
\hline & Pacov & Litvínov & Mohelnice & Černošice & Mar. Lázně & Konice \\
\hline
\end{tabular}

Source: compiled from Czech Statistical Office statistics (Census 2011).

\section{Hungary}

Hungarian agriculture had shown an unrivalled capacity within the Socialist block. Besides supplying the population of the country with high-quality products, its produce was exported to both eastern and western countries. It is therefore all the more intriguing that this sector went into a long downward spiral after the system changed. Production declined dramatically in the 1990s and for a long while it stayed about 30 per cent below the former average output. The average yields of all major crops also declined. While growth in industry began from 1994, and in other sectors of the national economy from 1996 and 1997, the agrarian sector faced a continuing and comprehensive crisis (Varga 2010).

One of the main ways the agrarian sector has adjusted to these competitive pressures is by continually reducing the amount of labour used by means of adopting new technology and structural adjustments such as larger farming units. The result in many regions is that agriculture now makes up a small part of total employment. However, even in these regions as well as those where agricultural employment is of much greater importance the inexorable trend of labour moving out of the sector seems to continue. In Hungary, due to restructuring in agriculture, privatization of former state-owned farms and compensation for farmers after the political transition (see Brown et al. 2006; Burger 2006), agricultural employment fell between 1980 and 2011 from approximately 20\% to less than 5\% (Source: HCSO - Hungarian Central Statistical Office) (Table 2).

The main reason for these changes was the lack of physical infrastructure (storage capacity, cold-chain storage, sorting, grading, packing, quality control and processing), and the lack of commercial-financial infrastructure (engrossers, creditors). In the traditional agricultural areas in Hungary (Szabolcs-Szatmár-Bereg, Békés, Hajdú-Bihar, Jász-Nagykun, Szolnok, Csongrád, Bács-Kiskun counties) the long term crisis increased to a point where social problems and unemployment became serious issues (Schlett and Beke 2014).

An interesting study made by Csatári (2005) was selected for the illustration of socio-economic processes and their relation to development of entrepreneurship in Hungarian rural areas. In the analyses Csatári (2005) adopted a multi-approach factor analysis as the method and examined at the level of general development of smaller regions in Hungary as well as the index of rurality. 
Table 2. Employment in Hungary and the European Union

\begin{tabular}{|c|c|c|c|c|c|c|c|c|c|}
\hline & \multicolumn{6}{|c|}{ Employment in agriculture* } & \multirow{2}{*}{\multicolumn{3}{|c|}{$\begin{array}{l}\text { Agriculture's share in Gross } \\
\text { Domestic Product in \% }\end{array}$}} \\
\hline & \multicolumn{3}{|c|}{$\begin{array}{c}1000 \text { employed in agriculture } \\
\text { (1000 persons) }\end{array}$} & \multicolumn{3}{|c|}{$\begin{array}{l}\text { Share in total employment } \\
\text { in } \%\end{array}$} & & & \\
\hline & EU25 & EU15 & HU & EU25 & EU15 & HU & EU25 & EU15 & HU \\
\hline 1980 & n.a. & 12,730 & 989 & n.a. & 9.5 & 19.5 & n.a. & n.a. & 17.0 \\
\hline 1990 & n.a. & 9,562 & 693 & n.a. & 6.6 & 14.2 & n.a. & n.a. & 12.5 \\
\hline 2000 & 10,680 & 6,770 & 246 & 5.7 & 4.3 & 6.5 & n.a. & 1.7 & 3.9 \\
\hline 2011 & $10,761 * *$ & 5,400 & 184 & $5.0 * *$ & 3.0 & 4.8 & $1.2 * *$ & 1.5 & 2.8 \\
\hline
\end{tabular}

*Including hunting, fishing and forestry, **EU-27

Source: Ritter et al. (2013) based on Eurostat and Hungarian Central Statistical Office (HCSO) data.

The most rural regions (mainly eastern Hungary) are at the same time the most undeveloped (Fig. 3-4). The level of development in eastern and southern Hungary has remained below the national average. Except in a few isolated urban regions, poor accessibility, high long-term unemployment, economic crises and the dominance of agriculture point to grave and entrenched economic and social conflicts. The unmistakable expansion of the suburban zones undergoing variegated development in the Budapest agglomeration, the island-like separation of large cities and a vigorous increase in the number of generally developed regions in northern and western Transdanubia is of major importance. Relative to this, predominantly agricultural rural regions are lagging behind, and are mainly concentrated on the Great Plain. A deep and persistent crisis in backward rural regions is typical of South Transdanubia and north eastern Hungary (Csatári 2005). Those studies and examples show the problems in finding a successful way to develop entrepreneurship in peripheral rural areas.

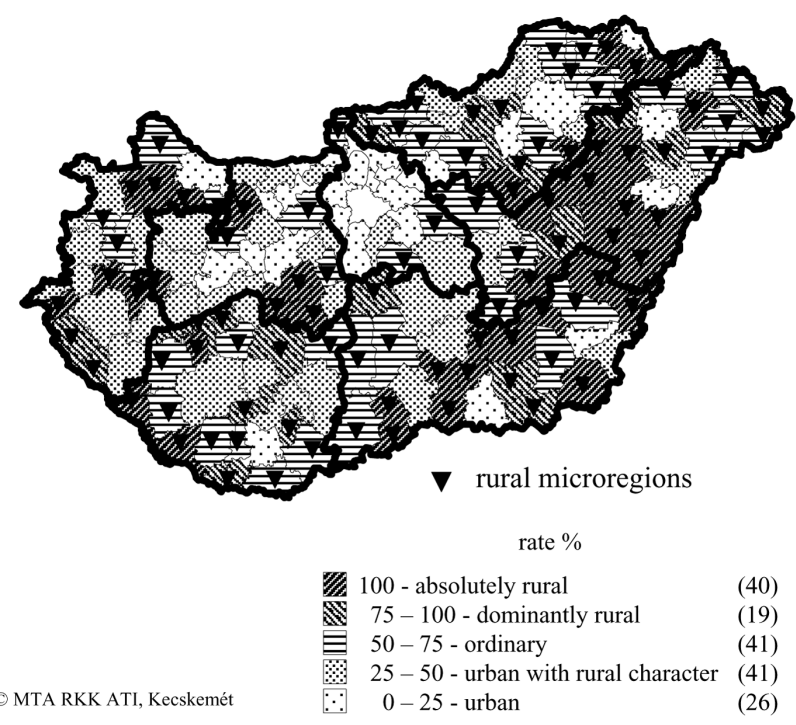

Fig. 3. Index of rurality in Hungary

Source: Csatári (2005). 


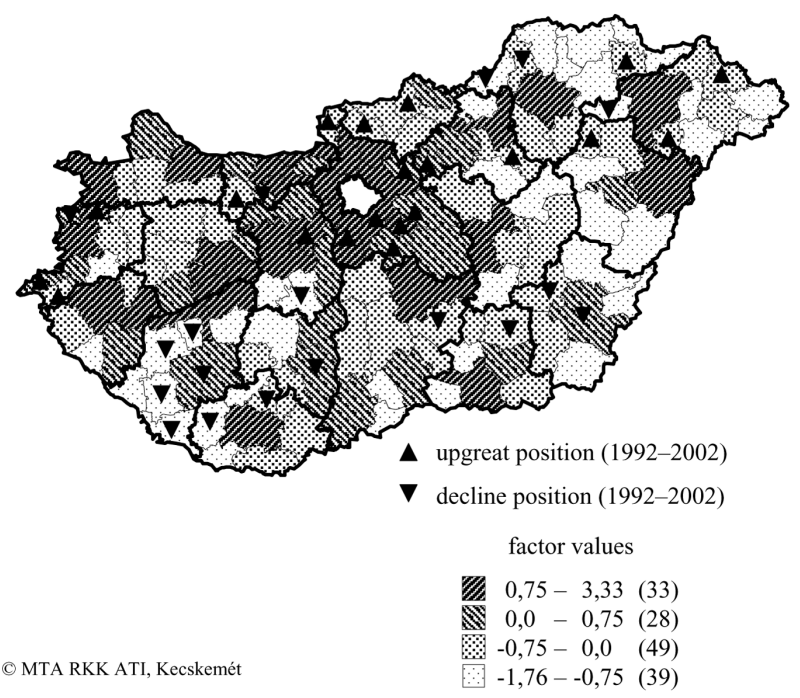

Fig. 4. Value of main factor of general socio-economic development Source: Csatári (2005).

\section{Poland}

Operation of private entrepreneurship under the socialist system was subject to numerous limitations (e.g. declining concessions, charging excessive taxation) and a rapid increase in the number of economic entities came only at the beginning of the transformation period (Misztal, 1989). Therefore, in 1988 the private sector in Poland was represented almost exclusively by trades, which mainly included industrial and construction activity and to a lesser extent agriculture services, public utilities and healthcare. In 1988 there was a more liberal approach towards trades consisting of easing restrictions related to the level of employment and expanding the scope of business activity while a rather restrictive policy on business and commercial services was still in force (Kamińska 2006). Starting in 1990, the number of companies began to increase dynamically.

The overall analysis of the entrepreneurship index leads to the conclusion that its value increases from east to west (with the exception of municipalities located within the Warsaw agglomeration). High rates of economic activity were observed in municipalities located in the vicinity of large cities and attractive tourist areas (coastal areas, Beskid and Bieszczady Mountains). The lowest level of this attribute was recorded in the Lubelskie Voivodeship and numerous municipalities of the Podkarpackie, Podlaskie and northern part of the Warmińsko-mazurskie Voivodeship (Kamińska 2011). The reasons behind the low level of economic activity in these areas include among others:

- low education level of the population (Kamińska 2011),

- monofunctionality - high share of employment in agriculture (Gałązka and Mync 1999),

- underdevelopment of financial infrastructure and institutions supporting entrepreneurship (Dutkowski and Gawlikowska-Hueckel 2000). 
It is also noteworthy to examine the size structure of business entities located in rural areas. According to the CSO these are in the vast majority micro-enterprises employing up to 9 people.

Based on analysis concerning changes of indicators describing entrepreneurship in rural areas in the first decade of the 21th century, one may ascertain considerable and stable dynamics in their development. However, it is crucial to distinguish the trends observed in relation to the type of rural areas. Most definitely, different conditions for the development of entrepreneurship prevail in areas with strong functional relations with urban centres of regional significance in comparison to monofunctional, agricultural areas located peripherally. Below is a brief analysis of this phenomenon in terms of functional structure.

The entrepreneurship index (number of entities per 1000 citizens of working age) suggests a general level of entrepreneurship in a given area. Since 2000 the number of economic entities in Poland has increased from 3,186,700 to 3,975,300, reaching an overall increase of $24.7 \%$. The growth rate was even greater in rural areas. In the municipalities of types $\mathrm{C}$ to $\mathrm{H}$ (explanations in the caption below Fig. 5) in the period of 2000-2012 the growth in the number of business entities was as high as $32.5 \%$. The least favourable situation was observed in notably agricultural communities, in which the value of the analysed indicator was the lowest throughout most of the examined period and the dynamics of change remained low (an increase of 11.6\%). Therefore, disparities deepen and notably agricultural communities (type D) stand out clearly from other municipalities in terms of the entrepreneurship index (94.9). The process of negative divergence does not pertain to municipalities with a relatively low prevalence of agricultural function (type E). Municipalities of this type have in recent years significantly improved their position in relation to notably agricultural communities.

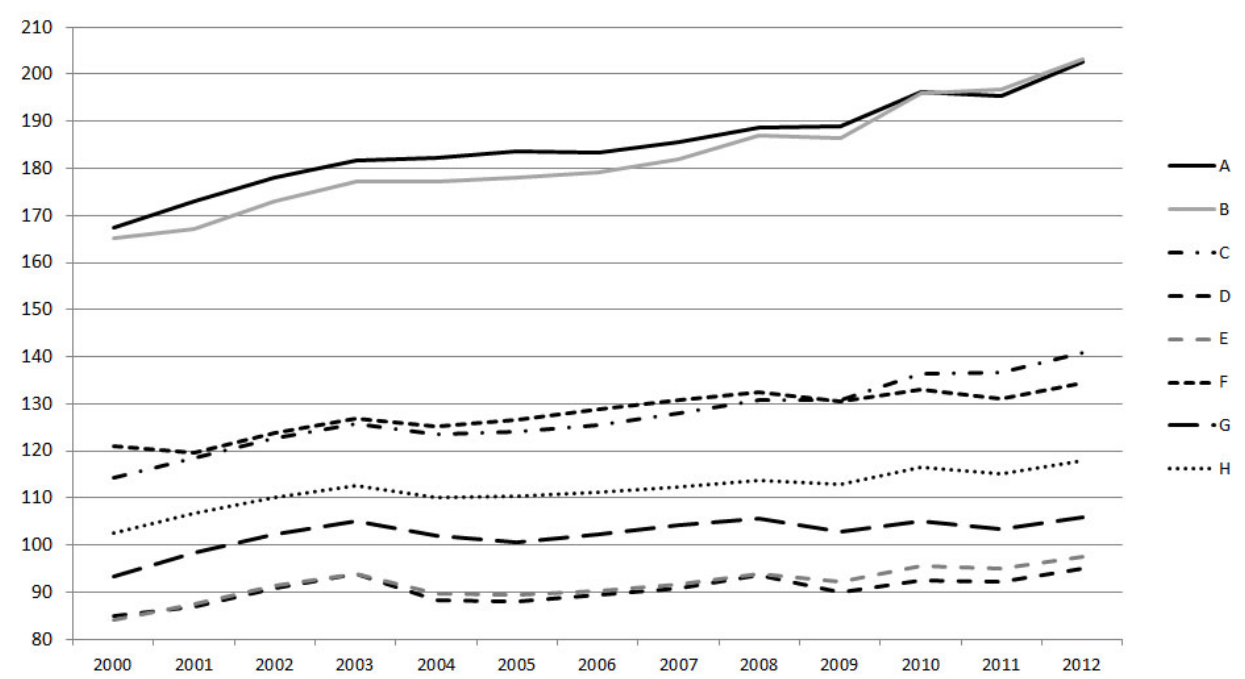

Fig. 5. Change in the value of the entrepreneurship index during the period 2000-2012 by the functional types of communes ( $\mathrm{A}$ - urban communes; B - urbanized areas; C - multifunctional transition areas; D - notably agricultural areas; $\mathrm{E}$ - predominantly agricultural areas; $\mathrm{F}$ - areas of tourism and recreation functions; $\mathrm{G}$ - areas of forest functions; $\mathrm{H}$ - areas of assorted functions) Source: own compilation based on Local Data Bank, CSO and methodology by Bański (2009). 


\section{Slovakia}

In Slovakia the main structuring mechanisms of the post-socialist transformation of agriculture were about the same as in Czechia, as both states constituted Czechoslovakia until 1993. As a result, agricultural employment dropped from 13 per cent to 3.2 per cent over the period 1990-2013 (Slovak Statistical Office and VúEPP 2014). If we look for the most agricultural district in Slovakia, measured by agricultural employment, then it is the district Gelnica with 24 per cent working in farming in 2009 (Slovak Statistical Office 2013).

Székely and Michniak (2009) conducted an interesting analysis of Slovak rural commuting centres (defined as municipalities with a population of less than 5,000 which offer jobs for more than 100 commuters and show a positive commuting balance. They discovered that agriculture, forestry and fishing is the dominating sector in only 12 out of 106 rural commuting centres. On the other hand, manufacturing dominates in 59 commuting centres (Fig. 6).

Michniak (2010) further focused on the 12 largest commuting centres whose economic centrality is based on one large employer in the electric power industry (Jaslovské Bohunice, Kalná nad Hronom, Vojany, Zemianské Kostol'any), the steel industry (Podbrezová), wood processing (Hencovce), the pharmaceutical industry (Slovenská L'upča), mining and metallurgy (Lubeník), sugar mill and cable production (Trenčianská Teplá), the electronics industry (Nižná), the rubber industry (Dolné Vesetnice) and the glass industry (Lednické Rovne). Most of these employers are successors of large socialist enterprises which were founded in Slovakia in the post-WWII period by the Czechoslovak state.

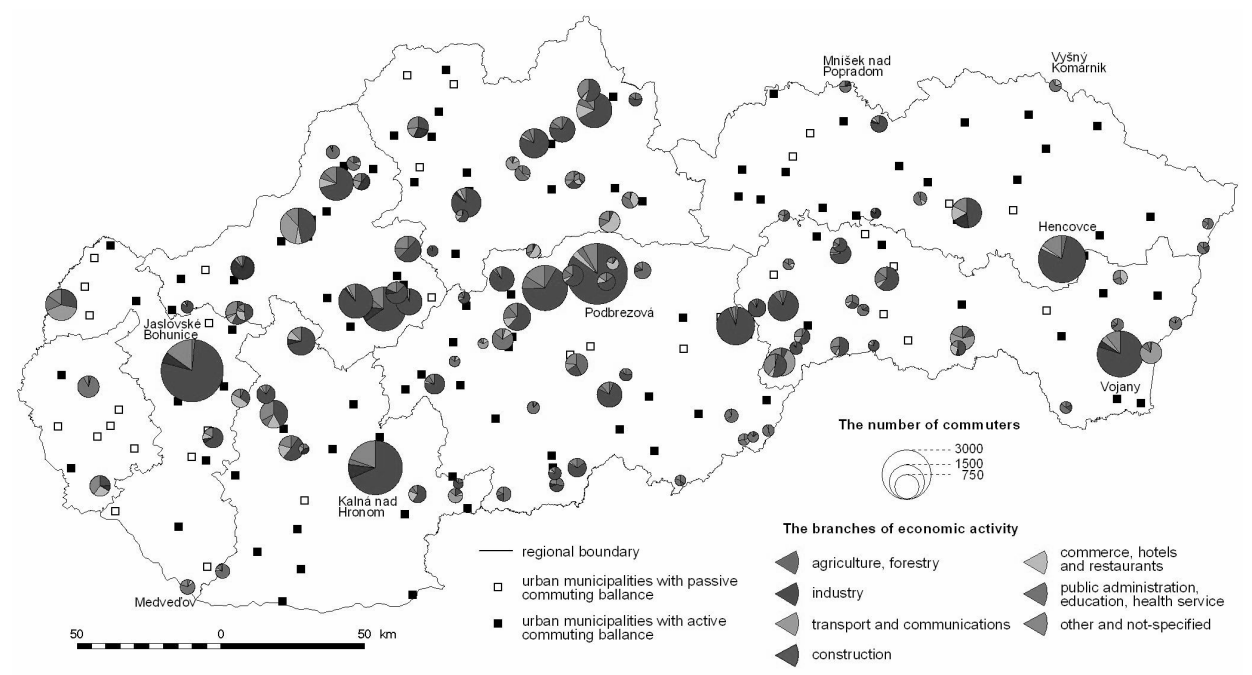

Fig. 3. Rural commuting centres of Slovakia and the structure of commuters by the branches of economic activity Source: Székely and Michniak (2009). 


\section{Causes of rural industrialization and tertiarization}

There are many theories and hypotheses with different theoretical backgrounds which aim to explain urban-rural manufacturing shift or the growth of employment in services in rural areas. As North (1998: 170) rightly comments, there are no simple right or wrong explanations, rather it is necessary to use them in a suitable context, because the expansion of manufacturing and services to rural areas involves many processes which are interrelated and have a different influence on the situation in a particular rural locality. Marini and Mooney (2006: 95) argue that reasons for the reversal in the flow of capital, goods and job opportunities from urban to rural areas consist in capital's search for cheaper labour, the creation of new markets and an influx of qualified and wealthy people from cities. North (1998: 170-173) suggests five hypotheses for the explanation of the urban-rural shift in manufacturing employment.

\section{The constrained location hypothesis}

This explanation reacts to the increasingly difficult situation of firms in urban areas when searching for new space for their further expansion. From this point of view small towns and rural areas are much more ready to provide new spacious units and land for expanding firms.

\section{The production cost hypothesis}

The production cost hypothesis is related to spatial variations in wage costs and land/property costs. In comparison with urban areas, rural areas and especially those in peripheral locations can offer lower costs for the expansion of new, space-demanding manufacturing investment.

\section{The filter down hypothesis}

This hypothesis relates the expansion of manufacturing to rural areas to the concept of product life cycles (e. g. Markusen 1985, similarly also Vernon 1966). With growing competition among firms since the end of the fordist era they have been forced to look for cheaper locations, where the more routine part of their production could be transferred. On the other hand, management, research, design and other activities requiring qualified labour are still located in metropolitan areas.

\section{The capital restructuring hypothesis}

This approach, derived from the Marxist theories, emphasizes the importance of spatial difference of labour. From this point of view the restructuring of production is connected to advances in technology and production methods. Such changes have also induced spatial changes where capital could flow much more quickly to areas which did not have a tradition in manufacturing. By this process, small towns and rural areas are preferred not only due to the lower wage costs, but also due to lower levels of unionization and worker militancy. This explanation is especially valid in the context of post-socialist countries whose economic restructuring has been driven by foreign direct investment which was perceived as regional development panacea (Mackinnon and Cumbers 2007) and enabled localisation of plants of TNCs in highly accessible rural areas. 


\section{The residential preference hypothesis}

This explanation puts together more behavioural aspects with entrepreneurial location decisions. Proponents of the residential hypothesis argue, that economic development in the form of new manufacturing and service start-ups in rural areas is related to the counterurbanization process. In-migrants to rural areas (especially wealthy and qualified members of the service class) are attracted by quality-of-life considerations and the (re) emergence of ecological, rural and local ideologies (Kiehl and Panebianco 2002). This explanation seems to be very promising since many studies (e.g. Smallbone 2005; Bosworth and Willett 2011; Kasimis et al. 2010; Bosworth and Glasgow 2012) have proven that in-migrants to rural areas have strong entrepreneurial thinking and therefore help to strengthen rural economies.

All the aforementioned hypotheses were developed by Western authors for rural areas of western developed countries, therefore it is necessary to think about and consider their relevance for the conditions of Visegrad countries. This is a logical call, because the positions adopted by British and American rural geography arose in a different historical and cultural context, a different perspective on the problem, and a different tradition in the evolution of social sciences. To rural geographers in Visegrad countries, issues of spatial structures and the influence of instruments of regional and agricultural policy of the European Union are of greater consequence, while social and cultural changes, especially in their local dimensions, are of lesser interest.

Since the 1990s, in these countries we can observe substantial technological progress (a rapid increase in personal mobility, modernization of the infrastructure of rural settlements etc.), later also the start of the counterurbanization process (still much more present in adjacent rural areas). The transformation of agriculture weakened its power position and terminated production in the premises of large state farms and cooperatives, therefore there has been a growth in free land and property stock which could have served as a haven for new small businesses. Some of these businesses could be perceived as indicators of new post-fordist conditions which arose on the remnants of large socialist enterprises. Other businesses are the result of intensifying global integration of post-socialist economies. Such integration has brought branch plants of transnational companies to rural areas whose arrival has been massively supported by national and regional governments which became empowered, similarly as local governments, by the decentralization of government and the end of central planning. These are all factors which have influenced the fortune of rural areas in Visegrad countries. It is necessary to put these factors into the context of the explanations mentioned above in order to explain what and how it has happened in the economies of rural areas in Visegrad countries.

\section{New rural economic areas and entrepreneurship in rural areas}

The economic activity of the population fundamentally affects the transformation of socio-economic space and contributes to improving the competitive position of given areas. The development of entrepreneurship is associated with both - favourable conditions for running a private business (natural, institutional and spatial conditions) and results from the knowledge and skill of residents. A desired location is usually the catalyst to exploit 
the potential rooted in society and initiative for action (Janc 2009). Audretsch and Keilbach (2005) even speak of entrepreneurship capital as part of human and social capital, which determines the social capability to establish new businesses.

Small and medium-sized enterprises play an important economic - activating local markets - and social role - encouraging the evolution of the middle class. The development of a single enterprise, which employs dozens of workers is significant for the local economy, even if it does not directly affect other producers in the region, as it generates multiplier consumption effects (Domanski 2001). Krugman (1999) states explicitly that successful locations are those that have a concentration of manufacturing activity.

Entrepreneurship is a multidimensional phenomenon determined by factors that can be encompassed under two spheres: social and economic (Karwat-Woźniak and Chmieliński 2006; Drucker 1992). The most frequently cited definition is the one of the Encyclopedia of Agribusiness (1998: 634): "Entrepreneurship involves an active, individual attitude interacting with reality as well as a general phenomenon that contributes to the improvement of existing economic resources and dependent socio-economic structures".

In the research on rural entrepreneurship, its significance for multifunctional rural development is emphasized, along with the gradual transformation of agricultural areas towards a more functionally diverse one. The concept of "multifunctional development of rural areas", derived from spatial planning is closely related to rural urbanization (Kostrowicki 1976). The concept of rural space as multifunctional space is considered as a by-product of a more general evolution of viewpoints in agricultural geography with respect to the modern nature of socio-economic transformation of rural areas. The concept of multifunctional rural development originated from an apparent need for new planning methods tailored to rural areas - that would follow structural changes that were rapidly taking place in the rural economy, including modernization of agriculture. The model for the functional structure of rural areas reappears in most modern-day geographical studies that tackle this topic.

Therefore, rural entrepreneurs and their companies become:

- a key factor for local development (Kłodziński 2006),

- an opportunity for non-agricultural rural development (Matysiak and Żmija 1996),

- an effective factor in the struggle against unemployment (Wojewoda 2002).

- The significance of different factors influencing the level of entrepreneurship in rural areas is differentiated:

- the impact of local government (Słomińska 2007),

- the importance of the human factor, an attitude towards entrepreneurship and education level of entrepreneurs (Czapiewski and Janc 2012),

- the role of technical, social and economic infrastructure in stimulating rural entrepreneurship (Dziura and Trzmiel 2011; Czapiewski 2004).

In the study on sectoral structure of undertaken initiatives, a fact is stressed that its scope usually encompasses minor services, including trade and craft activities as well as manufacturing (Kamińska 2006; Kłodziński 2006; Halamska 2013). In contrast, due to its distinctness and "rural specificity" much attention is addressed to agritourism (Szymańska 1996; Bednarek-Szczepańska 2010).

It is worth quoting the impression of rural entrepreneurship perceived through the prism of scientific discourse- local economy is an economy of many participants, but these are at the same time small entities, mainly micro-enterprises based on self-employ- 
ment; with a large share of the so-called "grey zone". Rural entrepreneurship is a place for individual or family work; with a high degree of flexibility and ability to retrain with the changing demand. Apart from the economic benefits, social and psychological benefits are equally important - having a job and securing redundant labour from agriculture are entities operating at the present time, not creating far-reaching development strategies, not regarding high levels of competition and often being uninterested in further development as well as little cooperation with other entities (Halamska 2013).

Concluding, the idea of innovative application of rural development is in accordance with the "bottom-up" approach recommended by OECD to increase the competitiveness of local communities and regions (Table 3 ). This approach differs from the former "top-down" with strengthening the role of investment and diminishing the role of direct support to stimulate development. Similarly to multifunctionality this new paradigm of rural development based on the exploitation of endogenous potentialities with expert knowledge. This new paradigm directly recommends equal treatment of rural activities and therefore equal access to support them. The former dominating role of central administration and farmers in directing regional development are to be distributed among all rural development stakeholders (Ray 1997; OECD 2006).

Table 3. The new paradigm of rural development

\begin{tabular}{|c|c|c|}
\hline & Old approach & New approach \\
\hline Objectives & $\begin{array}{l}\text { Equalisation, farm income, } \\
\text { farm competitiveness }\end{array}$ & $\begin{array}{l}\text { Competitiveness of rural areas, valorisation of local } \\
\text { assets, exploitation of unused resources }\end{array}$ \\
\hline Policy orientation & Sectoral & Territorial \\
\hline Key target sector & Agriculture & Various sectors of rural economies \\
\hline Main tools & Subsidies & Investments \\
\hline Key actors & $\begin{array}{l}\text { National governments, } \\
\text { farmers }\end{array}$ & $\begin{array}{l}\text { All levels of government (supranational, national, regional } \\
\text { and local), various local stakeholders (public, private, NGOs) }\end{array}$ \\
\hline
\end{tabular}

Source: OECD (2006).

In this light the successful process of rural development requires a shift from sector orientated to integrated economies branch strategies. This implies the involvement of different groups of local communities to coordinate sectors, social, environment and administration related development actions (Seibert 2006). This process is among the most difficult as it integrates a wide range of economic and social issues that are conditioned by local and regional environment. Therefore rural development can be recognised as a combination of different - community, business and administration - level sub actions (Strahl 2006). In this process the balance between public, private and different levels of governance actions is critical. In other words the level of complicity with these rules measures the harmony between desired development direction with the local specific environment and community preferences (OECD 2006). The complex nature of the new paradigm in rural development necessitates a combination of different types of knowledge. It includes management knowledge that is supported by local government authorities, local knowledge formed by the community and expert's knowledge that is mainly provided by NGO's and external experts. 


\section{Conclusion}

Rural areas of Visegrad countries follow, with a longer time lag, the development trajectories of other developed countries. A strong decline in agriculture, urban deindustrialization and rural industrialization, tertiarization of rural economies - these and other processes of post-socialist economic restructuring are building the present economies of rural areas of Visegrad countries.

However, economic growth is a highly unequal phenomenon - only some of these areas were able to find a successful strategy of development - in such areas the index of entrepreneurship is relatively high and this also helps to diversify the agriculture-dependent economy into a more diverse (multifunctional) and stable economy. Many rural areas could still be classified as lagging behind. The decline in the number of jobs in agriculture has not yet been replaced and they increasingly face social problems related to unemployment. Moreover, the difference in economic performance between them and rural areas adjacent to large urban centres is still increasing.

Economic growth is also unstable- usually highly accessible rural localities have benefited from the globalization process which has enabled them to commodify their location by hosting a plant of TNCs. Such a strategy brings many job opportunities to a particular rural area, nevertheless by another wave of capital accumulation such jobs could be relocated to regions or countries disposing with lower production costs.

From the above mentioned it is clear, that the spectrum of drivers which influence the development of non-agricultural and non-tourist activities in rural areas is very wide. Such factors are still not fully identified and classified - that is why it is difficult to make a holistic explanatory analysis. In any case, it has to be stressed that the economic importance of non-agricultural and non-tourist economic activities in present rural areas of Visegrad countries is not only larger, but will also grow in the future. Such economic activities become the crucial factor of rural economic growth. Simultaneously, the growing number of actors representing these activities will play an important role in the rural development process which has opened itself to a broader spectrum of key stakeholders according to the concept of the new rural paradigm implemented by the OECD.

\section{References:}

Atterton J., Bryden J., Johnson T., 2012, Rural economic transformations in the UK and US, [in:] Shucksmith M. et al., Rural transformations and rural policies in the US and UK, Routledge, London, pp. 117-137.

Audretsch D., Keilbach M., 2005, Entrepreneurship Capital and Regional Growth, Annals of Regional Science, 39, pp. 457-469.

Bański J., 2009, Typology for functional areas in Poland, MRD, Warsaw.

Bednarek-Szczepańska M., 2010, Rola podmiotów lokalnych w rozwoju turystyki wiejskiej na wybranych obszarach Lubelszczyzny, Studia Obszarów Wiejskich, 23.

Bičík I., Jančák V., 2005, Transformační procesy v českém zemědělství po roce 1990, Katedra sociální geografie a regionálního rozvoje Prírodovědecké fakulty Univerzity Karlovy, Praha.

Bosworth G., Willett J., 2011, Embeddedness or escapism? Rural perceptions and economic development in Cornwall and Northumberland, Sociologia Ruralis, 51, pp. 195-214. 
Bosworth G., Glasgow N., 2012, Entrepreneurial Behaviour among Rural In-migrants, [in:] Shucksmith M. et al., Rural transformations and rural policies in the US and UK, Routledge, London, pp. 138-155.

Brown D. J., Earle J. S., Telegdy Á., 2006, The productivity effects of privatization: Longitudinal estimates from Hungary, Romania, Russia, and Ukraine. Journal of Political Economy, 1, pp. 61-99.

Burger A., 2006, Why is the issue of land ownership still of major concern in East Central European (ECE) transitional countries and particularly in Hungary? Land Use Policy, 4, pp. 571-579.

Burton R., 2004, Seeing through the 'good farmer's' eyes: towards developing an understanding of the social symbolic value of 'productivist' behaviour, Sociologia Ruralis, 44, pp. 195-215.

Csatári B., 2005, Major changes in the Hungarian micro-regions, Rural areas and development, 3, pp. 79-94.

Czapiewski K., Janc K., 2012, Rola wiedzy na wsi-edukacja a praca, [in:] Kamińska W., Heffner K. (eds.), 2012, Wiejskie rynki pracy - zasoby, aktywizacja, nowe struktury, Warszawa, Studia KPZK PAN, 145, pp. 278-301.

Czapiewski K., 2004, Wyposażenie infrastrukturalne i potencjał gospodarczy obszarów wiejskich a pozarolnicze funkcje gmin, [in:] Pałka E., Pozarolnicza działalność gospodarcza na obszarach wiejskich, Warszawa, Studia Obszarów Wiejskich, 5, pp. 57-73.

Doležal P., 2015, Vývoj počtu obsazených pracovnich mist na českém venkově od roku 1991, Master thesis, Univerzita Jana Evangelisty Purkyně, Ústí nad Labem.

Domański B., 2001, Czynniki społeczne w lokalnym rozwoju gospodarczym we współczesnej Polsce, [in:] Sagan I., Czepczyński M. (eds), Wybrane problemy badawcze geografii społecznej w Polsce, Uniwersytet Gdański, Gdynia, pp. 127-134.

Drucker P. F., 1992, Innowacja i przedsiębiorczość, Praktyka i zasady, PWE, Warszawa.

Dutkowski M., Gawlikowska-Hueckel K., 2000, Sytuacja społeczno-gospodarcza nowych województw, IBnGR, Gdańsk.

Dziura M., Trzmiel T., 2011, Infrastruktura komunalna jako czynnik rozwoju przedsiębiorczości, Zeszyty Naukowe, Wyższa Szkoła Ekonomii i Informatyki w Krakowie, 7, pp. 9-49.

Encyklopedia Agrobiznesu, 1998, Fundacja Innowacja, Warszawa.

Fløysand A., Sjøholt P., 2007, Rural Development and Embeddedness: The Importance of Human Relations for Industrial Restructuring in Rural Areas, Sociologia Ruralis, 47, pp. 205-227.

Fothergill S., Gudgin G., 1982, Uneaqual growth: urban and regional employment change in the UK, Heinemann, London.

Gałązka A., Mync A., 1999, Zmiany społeczno-gospodarcze na obszarach przygranicznych warunkach otwierajacych się granic [in:] Mync A., Szul R. (eds), Rola współpracy trans granicznej w rozwoju regionalnym i lokalnym, Europejski Instytut Rozwoju Regionalnego i Lokalnego UW, Warszawa, pp. 42-111.

Halamska M., 2013, Wiejska Polska na poczqtku XXI wieku. Rozważania o gospodarce i społeczeństwie, Wydawnictwo Naukowe Scholar, Warszawa.

Hruška V., 2014, Rural Studies and Uneven Development of Rural Areas in Central Europe. [in:] Koutský J., Raška P., Dostál P., Herrschel T. (eds.), Transitions in Regional Science - Regions in Transition: Regional research in Central Europe. Wolters Kluwer, Praha, pp. 47-65.

Ilbery B., Bowler I., 1998, From agricultural productivism to post-productivism, [in:] Ilbery, B. (ed), The geography of rural change, Longmann, Essex, pp. 57-84.

Janc K., 2009, Zróżnicowanie przestrzenne kapitału ludzkiego i społecznego w Polsce, Rozprawy Naukowe Instytutu Geografii i Rozwoju Regionalnego, 8, IGRR UWr, Wrocław. 
Kamińska W., 2006, Pozarolnicza indywidualna działalność gospodarcza w Polsce w latach 1988-2003, Prace Geograficzne, 203, IGiPZ PAN, Warszawa.

Kamińska W., 2011, Aktywność gospodarcza osób fizycznych na obszarach wiejskich w Polsce, [in:] Kamińska W., Heffner K. (eds), Obszary wiejskie: wielofunkcyjność, migracje, nowe wizje rozwoju, Studia KPZK PAN, 133, pp. 103-127.

Karwat-Woźniak B., Chmieliński P., 2006, Praca w indywidualnych gospodarstwach rolnych, IERiGŻ-PIB, Warszawa.

Kasimis C., Papadopoulos A., Pappas C., 2010, Gaining from rural migrants: migrant employment strategies and socio-economic implications for rural labour markets, Sociologia Ruralis, 50, pp. 258-276.

Keeble D., 1980, Industrial decline, regional policy and the urban-rural manufacturing shift in the United Kingdom, Environment and Planning A, 12, pp. 945-962.

Keeble D., Owens P., Thompson C., 1983, The urban-rural manufacturing shift in the European Community, Urban Studies, 20, pp. 405-418.

Kiehl M., Panebianco S., 2002, The urban-rural employment shift in Western Europe: an empirical analysis of the employment development in Britain, Germany and Italy, Paper presented the $42^{\text {nd }}$ Congress of the European Regional Science Asociation (ERSA), Dortmund, 27-31 August 2002.

Kłodziński M., 2006, Aktywizacja społeczno-gospodarcza gmin wiejskich i małych miast, IRWiR PAN, Warszawa.

Kostrowicki J., 1976, Obszary wiejskie jako przestrzeń wielofunkcyjna, Zagadnienia badawcze i planistyczne, Przegląd Geograficzny, 48, pp. 601-611.

Krugman P., 1999, Development, Geography, and Economic Theory, The MIT Press, London.

Lapping M., 2006, Rural policy and planning, [in:] Cloke P., Marsden T., Mooney P. (eds), Handbook of rural studies, SAGE, London, pp. 104-122.

Lonsdale L., Seyler H., (eds), 1979, Non-metropolitan industrialization, Halsted Press, New York.

Lowe P., Murdoch J., Marsden T., Munton R., Flynn A., 1993, Regulating the new rural spaces: the uneven development of land, Journal of Rural Studies, 9, pp. 205-222.

Mackinnon D., Cumbers A., 2007, An introduction to economic geography: globalization, uneven development and place, Pearson, Edinburgh.

Marini M., Mooney P., 2006, Rural economies, [in:] Cloke P., Marsden T., Mooney P. (eds), Handbook of rural studies, SAGE, London, pp. 91-103.

Markusen A., 1985, Profit cycles, oligopoly and regional development, MIT Press, Cambridge.

Matysik R., Żmija J., 1996, Agrobiznes szansq rozwoju wsi i rolnictwa Małopolski, Prace Naukowe Akademii Ekonomicznej we Wrocławiu, 741, pp. 80-85.

Michniak D., 2010, Najvýznamnejšie vidiecke centrá zamestnanosti na Slovensku, [in:] Fňukal M., Frajer J., Hercik J. (eds), 50 let geografie na Př́rodovědecké fakultě Univerzity Palackého v Olomouci, Prírodovědecká fakulta Univerzity Palackého v Olomouci, Olomouc, pp. 443-452.

Misztal S., 1989, Rozwój przemysłu na Mazowszu, Biuletyn Instytutu Gospodarstwa Społecznego SGH, 32, pp. 70-156.

North D., 1998, Rural industrialization, [in:] Ilbery B. (ed). The geography of rural change, Longmann, Essex, pp. 161-188.

OECD, 2006, The New Rural Paradigm. Policies and Governance. OECD, Paris.

OECD, 2008, Territorial Database, OECD, [cit. 2013-01-20]: URL: http://www.oecd.org/gov/regional-policy/regionalstatisticsandindicators.htm.

OECD, 2010, Agricultural Policies and Rural Development - a Synthesis of Recent Work, OECD, Paris. 
Ray C., 1997, Towards a theory of the dialectic of rural development, Sociologia Ruralis, 27, pp. 345-362.

Ritter K., Szabó V., Nagyné Pércsi K., 2013, Rural Restructuring and the Role of Agriculture in Rural Areas of Hungary after Post-Socialist Transformation, [in:] Babjaková B., Bandlerová A., Brown D., Kaleta A., Kulcsar L., Singelmann J. (eds), Social and Economic Transformations Affecting Rural People and Communities in Central and Eastern Europe Since 1990, Slovak University of Agriculture in Nitra, Nitra, pp. 86-96.

Schlett A., Beke J., 2014, Agriculture and employment. Hungarian agriculture before and after the transition, Economic Questions and Enterprise Management, 3, pp. 47-56.

Seibert O., 2006, Czynniki sukcesu zintegrowanego rozwoju regionalnego, Fundacja im. Heinricha Bölla, Warszawa.

Słomińska B., 2007, Gmina w procesach stymulowania przedsiębiorczości, Samorząd Terytorialny, 3, pp. 19-33.

Smallbone D., 2005, Fostering Entrepreneurship in rural areas, [cit. 2015-01-20]: URL: http://www. oecd.org/site/cfecpr/42203059.pdf.

Strahl D. (ed.), 2006, Metody oceny rozwoju regionalnego, Wydawnictwa Akademii Ekonomicznej, Wrocław.

Synek M., 2004, Transformace, restrukturalizace, revitalizace, Acta Oeconomica Pragensia, 2004, pp. 170-195.

Székely V., Michniak D., 2009, Rural municipalities of Slovakia with a positive commuting balance, European Rural Development Network Studies, 6, pp. 303-319.

Szymańska J., 1996, Agroturystyka forma kreowania przedsiębiorczości wiejskiej, Prace Naukowe Akademii Ekonomicznej we Wrocławiu, 741, pp. 129-134.

Varga Z., 2010, The post-Socialist transformation of land ownership in Hungary, [in:] Congost R., Santos R. (eds.) Contexts of Property in Europe. The Social Embeddedness of Property Rights in Land in Historical Perspective, Turnhut, Brepols, pp. 267-285.

Vernon R., 1966, International investment and international trade in the product cycle, Quaterly Journal of Economics, 80, pp. 190-207.

VÚEPP, 2014, Správa o pol'nohospodárstve a potravinárstve v Slovenskej republike za rok 2013, (Zelená správa), VÚEPP, Bratislava.

Wojewoda I., 2002, Aktywizacja działalności pozarolniczej w walce z bezrobociem na wsi, Prace Naukowe Akademii Ekonomicznej we Wrocławiu, 941, pp. 476-482.

Woods M., 2005, Rural geography: Processes, Responses and Experiences in Rural Restructuring, SAGE, London.

Woods M., 2011, Rural, Routledge, London. 